\title{
Catalytic carbon deposition-oxidation over Ni, Fe and Co catalysts: A new indirect route to store and transport gas hydrocarbon fuels
}

\author{
Patrícia E.F. Oliveira a , Leandro P. Ribeiro a , Marcelo G. Rosmaninho a , José D. Ardisson ${ }^{\text {b }}$, Anderson Dias ${ }^{\text {c }}$, \\ Luiz C.A. Oliveira ${ }^{a}$, Rochel Montero Lago ${ }^{a, *}$ \\ a Departamento de Química, Universidade Federal de Minas Gerais. Belo Horizonte, MG, Brasil \\ b Laboratório de Física Aplicada, CDTN. Belo Horizonte, MG, Brasil \\ c Departamento de Química, Universidade Federal de Ouro Preto. Ouro Preto-MG, Brasil
}

\section{A R T I C L E I N F O}

\section{Article history:}

Received 12 September 2012

Received in revised form 19 November 2012

Accepted 21 November 2012

Available online 28 November 2012

\section{Keywords:}

Natural gas

C deposition-oxidation

Syngas production

\begin{abstract}
A B S T R A C T
In this work, a new two-step route to store and transport associated natural gas, promoted by $\mathrm{Ni}$, Fe and $\mathrm{Co}$ supported catalyst was presented. Initially, $\mathrm{CH}_{4}$ is converted into carbon deposits ( $\mathrm{M} / \mathrm{C}$ composite), being Fe catalyst the most active catalyst. In Step 2, M/C composite reacts with $\mathrm{H}_{2} \mathrm{O}$ producing $\mathrm{H}_{2}, \mathrm{CO}$ and $\mathrm{CH}_{4}$. TPO experiments showed that efficiency and selectivity of oxidation depends on the metal. Ni catalyst produced mainly $\mathrm{H}_{2}$ and $\mathrm{CO}$, while Fe system was more selective to convert carbon into $\mathrm{CH}_{4}$. The formation of $\mathrm{C}_{2}$ and $\mathrm{C}_{3}$ compounds suggests the presence of a Fischer Tropsch like process.
\end{abstract}

(c) 2012 Published by Elsevier B.V.

\section{Introduction}

Offshore petroleum exploration coproduces large amounts of a gas composed of light hydrocarbons ranging from methane to hexane [1]. This gas fraction has many potential industrial and economical uses, e.g. production of energy, syngas and other chemicals. However, due to operational difficulties and high costs of gas transportation most of this associated gas is simply released or burnt to the atmosphere [2]. Therefore, cost effective technologies to use this associated natural gas lost in offshore exploration is of considerable interest.

In this work, we present a completely new concept in storage and transportation of natural gas lost in petroleum offshore exploration based on a two steps cycle composed of: (i) catalytic carbon deposition and (ii) steam oxidation. In the first step, at the offshore platform, a metal oxide is reacted with the associated natural gas $\left(\mathrm{CH}_{4}\right)$ to produce the reduced metal and deposits of carbon (Eqs. (1) and ((2)). This M/C composite can then be stored and transported to the shore. In a second step, the $\mathrm{M} / \mathrm{C}$ composite is reacted with steam to produce syngas ( $\mathrm{CO}$ and $\mathrm{H}_{2}$ ) (Eq. ((3)) and converted to hydrocarbons by the well known Fischer Tropsch process (Eq. (4)). This cycle is shown schematically in Fig. 1.

MOxide $+\mathrm{CH}_{4} \rightarrow \mathrm{M}+\mathrm{CO}_{\mathrm{x}} / \mathrm{H}_{2} \mathrm{O}$

$\mathrm{M}+\mathrm{CH}_{4} \rightarrow \mathrm{M} / \mathrm{C}+\mathrm{H}_{2}$

\footnotetext{
* Corresponding author. Tel.: +55 313409 5719; fax: +55 3134095700. E-mail address: rochel@qui.ufmg.br (R.M. Lago).
}

$\mathrm{M} / \mathrm{C}+\mathrm{xH}_{2} \mathrm{O} \rightarrow \mathrm{CO}+\mathrm{H}_{2}+$ MOxide

$\mathrm{nCO}+(2 \mathrm{n}+1) \mathrm{H}_{2} \rightarrow \mathrm{C}_{\mathrm{n}} \mathrm{H}_{2 \mathrm{n}+2}+\mathrm{nH}_{2} \mathrm{O}$

Recently an indirect storage and production of $\mathrm{H}_{2}$ from bioethanol based on a redox iron system [3] has been described where iron oxide is reduced under controlled conditions by ethanol to form $\mathrm{Fe}^{0}$, which can be easily stored and transported. When necessary, $\mathrm{Fe}^{0}$ can be reacted with water to produce $\mathrm{H}_{2}$ [3]. This iron redox system has also been used to purify $\mathrm{H}_{2}$ from $\mathrm{H}_{2} / \mathrm{CO}$ mixtures produced by coal gasification $[4,5]$. This reaction is based on the Fe oxide reduction to $\mathrm{Fe}^{\circ}$ by a $\mathrm{H}_{2}$ and $\mathrm{CO}$ mixture. The obtained metallic Fe can then be reacted with $\mathrm{H}_{2} \mathrm{O}$ to produce pure $\mathrm{H}_{2}$ for different applications. The purpose of this work is to apply a new process combination of deposition-oxidation in order to store, transport and produce syngas from methane lost in offshore exploration.

Hereon, we present the results obtained for the cycle in Fig. 1 in the presence of three different catalysts, i.e. $\mathrm{Ni}$, Fe and Co supported on $\mathrm{Al}_{2} \mathrm{O}_{3}$. All these metals can promote both steps of the catalytic cycle, i.e. carbon deposition from hydrocarbons [6-10] and steam reform of carbonaceous materials to syngas [11-18]. Moreover, Ni, Fe and Co catalysts have different behavior in the presence of syngas. For example, Ni catalysts hydrogenate $\mathrm{CO}$ to produce mainly methane $[19,20]$, whereas cobalt and iron can promote the classical Fischer Tropsch synthesis from syngas [21-29]. We will disclose preliminary results on the effect of $\mathrm{Ni}$, Fe and Co catalysts for the direct production of hydrocarbons during the steam oxidation step. 


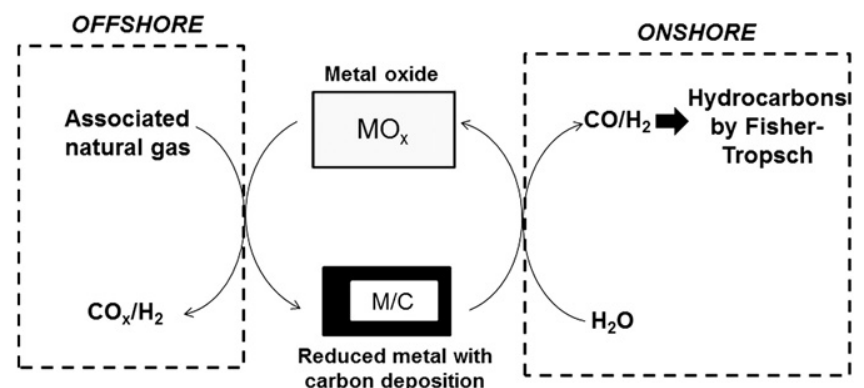

Fig. 1. Schematic representation of the two steps process of carbon deposition and steam oxidation using associated natural gas lost in offshore oil exploration.

\section{Experimental}

\subsection{Synthesis and characterization of catalysts}

The catalysts were prepared by wet impregnation of $\mathrm{Fe}, \mathrm{Ni}$ and $\mathrm{Co}$ nitrates on alumina $\left(140 \mathrm{~m}^{2} \mathrm{~g}^{-1}\right)$, with nitrate containing calculated to produce materials with $10 \% \mathrm{w} / \mathrm{w}$ of the metal oxide named hereon Fe10A, Ni10A and Co10A, respectively. The metal content in the catalysts, determined by atomic absorption spectroscopy, was $10 \% \pm 0.3$. After impregnation and drying at $110{ }^{\circ} \mathrm{C}$ for $12 \mathrm{~h}$, the catalysts were calcined at $400{ }^{\circ} \mathrm{C}$ in air for $4 \mathrm{~h}$.

\subsection{Temperature programmed chemical vapor deposition (Step 1)}

Methane decomposition was performed in a conventional gas-flow system with a fixed catalyst bed. Diluted methane (14\% in nitrogen) was used in order to obtain higher sensibility for the TPCVD experiments. The powder catalyst $(10 \mathrm{mg}$ ) was packed in a quartz tubular reactor and heated at $5{ }^{\circ} \mathrm{C} \mathrm{min}{ }^{-1}$ from 25 to $900{ }^{\circ} \mathrm{C}$ in the $\mathrm{CH}_{4} / \mathrm{N}_{2}$ stream at $22 \mathrm{~mL} \mathrm{~min}^{-1}$ to obtain an WHSV of $85 \mathrm{~h}^{-1}$ (considering temperature of $25{ }^{\circ} \mathrm{C}$ ). Methane concentration final temperature was maintained for $1 \mathrm{~h}$. During the reaction, volatile products were analyzed by a gas chromatography (Shimadzu Model GC-2010), equipped with TCD and FID detectors and an injector connected to a Carboxen-1010 column. GC calibration was done with a standard mixture (Air Liquide) containing $3.5 \mathrm{~mol} \%$ of each gas, i.e. $\mathrm{H}_{2}, \mathrm{CO}, \mathrm{CO}_{2}, \mathrm{CH}_{4}, \mathrm{C}_{2} \mathrm{H}_{6}, \mathrm{C}_{2} \mathrm{H}_{4}$ and $\mathrm{C}_{2} \mathrm{H}_{2}$ in $\mathrm{N}_{2}$.

\subsection{Composites $M / C$ characterization}

Metal-carbon composites were characterized by Mössbauer spectroscopy (CMTE spectrometer model MA250 with a ${ }^{57} \mathrm{Co} / \mathrm{Rh}$ source at room temperature using $\alpha-\mathrm{Fe}^{\circ}$ as reference), X-ray diffraction (Rigaku $\mathrm{D} \mid \mathrm{MAX}$, with $\mathrm{Cu}$ tube, $2 \theta$ from 5 to $70^{\circ}$ and scanning velocity of $4^{\circ}$ min $^{-1}$ ), scanning electron microscopy (SEM) (Jeol JKA 8900RL) and Raman spectroscopy (HORIBA LabRAM HR, He-Ne excitation laser with wavelenght of $632.8 \mathrm{~nm}$ ). Thermal analyses (TG/DTG/DTA) were carried out in a DTG $60 \mathrm{H}$ Shimadzu, with the following conditions: air flow of $100 \mathrm{~mL} \mathrm{~min}{ }^{-1}$ and heating rate $10{ }^{\circ} \mathrm{C} \mathrm{min}^{-1}$.

\subsection{Temperature programmed oxidation (Step 2)}

The $M / C$ composites obtained in Step 1 were submitted to the oxidation with water. In this second step, $\mathrm{N}_{2}\left(40 \mathrm{~mL} \mathrm{~min}^{-1}\right)$ was used to carrier water from a saturator held at $25{ }^{\circ} \mathrm{C}$ (vapor pressure of $3,15 \mathrm{kPa}$, $3,1 \mathrm{~mol} \%$ of water), thereby an WHSV of $162 \mathrm{~h}^{-1}$ The materials were heated up to $900{ }^{\circ} \mathrm{C}$, keeping this temperature for $1 \mathrm{~h}$. The production of syngas, methane and other compounds was accompanied by GC analyses as described above.

\section{Results and discussion}

\subsection{Catalysts characterization}

Three different catalysts based on $\mathrm{Fe}$, $\mathrm{Co}$ and $\mathrm{Ni}$ supported on $\mathrm{Al}_{2} \mathrm{O}_{3}$ were prepared by wet impregnation. Preliminary work in our laboratory showed that metal contents ca. $10 \mathrm{wt}$.\% produced the best carbon yields (Supplementary Material). X-ray diffraction patterns of the catalyst precursors showed the presence of the corresponding metallic oxides, $\mathrm{Fe}_{2} \mathrm{O}_{3}, \mathrm{Co}_{3} \mathrm{O}_{4}$ and NiO. For Co10A, cobalt aluminates, e.g. $\mathrm{Co}_{2} \mathrm{AlO}_{4}$ and $\mathrm{CoAl}_{2} \mathrm{O}_{4}$ were also identified (Supplementary Material).

\subsection{Temperature programmed chemical vapor deposition TPCVD (Step 1)}

TPCVD reactions initiate with the reduction of the Ni, Co and Fe oxides by methane to produce the reduced metal. Mechanistic investigations [30-32] suggest that this reduction involves hydrogen abstraction by the oxide surface to form species $\mathrm{M}-\mathrm{OH}$ and $\mathrm{M}-\mathrm{O}-\mathrm{CH}_{3}$ that further decompose to the main products $\mathrm{H}_{2} \mathrm{O}$ and $\mathrm{CO}_{\mathrm{x}}$. The reduced metal works as catalyst in carbon deposition and $\mathrm{H}_{2}$ production. Since its formation, $\mathrm{H}_{2}$ acts as reducer specie, promoting the reduction of remaining metal oxide. [33].

For Fe10A catalyst, Mössbauer spectra (Supplementary Material) showed that the catalyst precursor, mainly $\mathrm{Fe}_{2} \mathrm{O}_{3}$ and highly dispersed $\mathrm{Fe}^{3+}$ species, is reduced to $\mathrm{Fe}^{0}(9 \%)$ and other $-\mathrm{Fe}(\mathrm{C}), 14 \%$, and $\mathrm{Fe}_{3} \mathrm{C}$ (71\%) formed during carbon deposition.

The difference between catalysts behavior in carbon deposition strongly depends on the metal and other various characteristics of the system as clearly shown for Ni, Fe and Co by Narkiewicz et al. [6].

Profiles of methane consumption and $\mathrm{H}_{2}$ production during the carbon deposition (Step 1) are shown in Fig. 2. All the obtained profiles showed methane conversion by a decrease of the GC signal followed by a return back to the baseline indicating the catalyst deactivation. Hydrogen production follows exactly the same $\mathrm{CH}_{4}$ consumption profile suggesting carbon deposition according to Eq. ((2). Fig. 2 also shows that in the presence of Ni10A, methane decomposition initiated at relatively lower temperatures, ca. $600{ }^{\circ} \mathrm{C}$. Co10A reacted with methane only
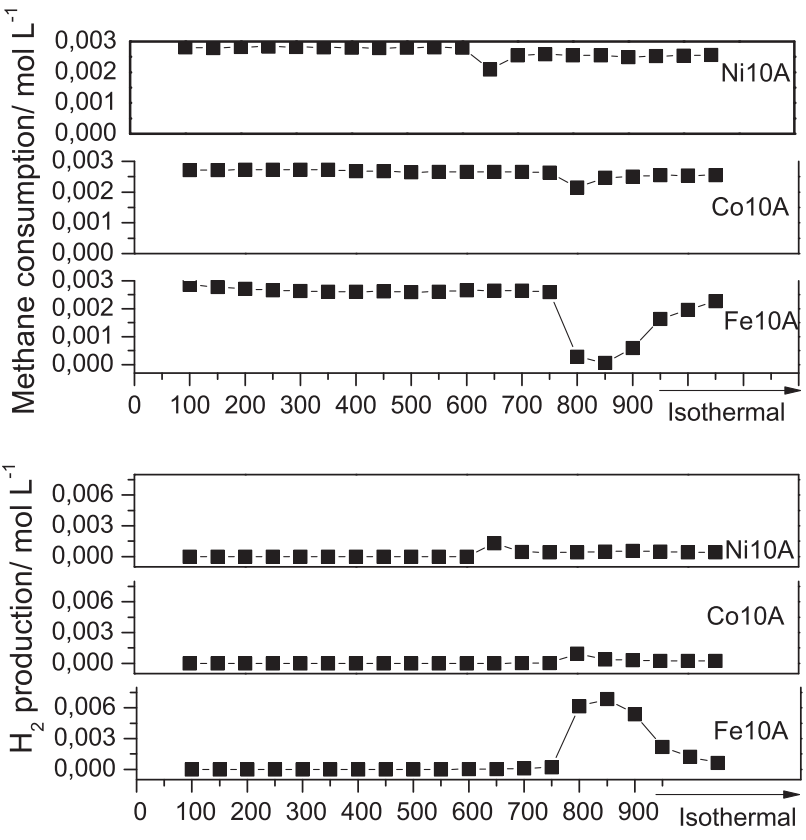

Temperature $/{ }^{\circ} \mathrm{C}$

Fig. 2. Temperature programmed methane consumption (a) and $\mathrm{H} 2$ production (b) during Step 1. 
at higher temperature, i.e. $750{ }^{\circ} \mathrm{C}$, and deactivated rapidly. Fe10A also reacted with methane at $750{ }^{\circ} \mathrm{C}$ but remained active for a longer time.

The yields of carbon produced were determined by TG weight losses in the temperature range ca. $400-700{ }^{\circ} \mathrm{C}$ (Supplementary Material). These weight losses are related to the oxidation of the formed carbon by air. Fe10A, Ni10A and Co10A showed carbon contents of ca. 23,18 and $9 \%$, respectively with estimated atomic C/M ratio of 20 , 13 and 8.

Scanning electron microscopy images (Supplementary Material) showed formation of carbon deposits as organized structures such as filaments, especially for Fe10A catalyst. In fact, Raman spectra of the composites obtained for Fe10A (Fig. 3) showed higher G/D band intensity ratio, $\mathrm{I}_{\mathrm{G}} / \mathrm{I}_{\mathrm{D}}=1.17$, compared the value obtained for $\mathrm{Ni}$ and $\mathrm{Co}$, ca. 0.9. The $\mathrm{G}$ band is related to more organized carbon structures whereas the $\mathrm{D}$ band can be associated to more amorphous or defectives carbon structures [34]. This result suggests that Fe10A produced more organized carbon structures compared to $\mathrm{Ni}$ and $\mathrm{Co}$ based catalysts.

\section{Temperature programmed oxidation with $\mathrm{H}_{2} \mathrm{O}$ (Step 2)}

The oxidation of the produced M/C composites with $\mathrm{H}_{2} \mathrm{O}$ (Step 2) was investigated by temperature programmed oxidation TPO (Fig. 4). During these reactions, the main products observed were $\mathrm{H}_{2}, \mathrm{CO}$ and methane.

Ni10A showed two peaks of $\mathrm{H}_{2}$ production, i.e. a more pronounced peak centered at ca. $600^{\circ} \mathrm{C}$ and another less intense at $850{ }^{\circ} \mathrm{C}$ (Fig. 4a). It is interesting to observe that $\mathrm{H}_{2}$ is produced without $\mathrm{CO}$ up to $500{ }^{\circ} \mathrm{C}$ suggesting the oxidation of $\mathrm{Ni}^{\circ}$ by $\mathrm{H}_{2} \mathrm{O}$ to produce only $\mathrm{H}_{2}$ according to Eq. (5):

$\mathrm{Ni}^{\mathrm{o}}+\mathrm{H}_{2} \mathrm{O} \rightarrow \mathrm{H}_{2}+\mathrm{NiO}$

The production of small amounts of methane suggests that another reaction pathway below $500{ }^{\circ} \mathrm{C}$ can be the oxidation of carbon to form $\mathrm{CO}$ (Eq. (6)) followed by a rapid Ni catalyzed hydrogenation to methane (Eq. (7)):

$\mathrm{C}+\mathrm{H}_{2} \mathrm{O} \rightarrow \mathrm{H}_{2}+\mathrm{CO}$

$\mathrm{CO}+2 \mathrm{H}_{2} \rightarrow \mathrm{CH}_{4}+\mathrm{H}_{2} \mathrm{O}$

At higher temperatures, $\mathrm{H}_{2}$ and $\mathrm{CO}$ are produced concomitantly suggesting the occurrence of carbon oxidation by $\mathrm{H}_{2} \mathrm{O}$. The $\mathrm{H}_{2} / \mathrm{CO}$ ratio of ca. 3.5 at $600{ }^{\circ} \mathrm{C}$ suggests the presence of both reactions described in Eqs. (5) and (6). On the other hand, at $850{ }^{\circ} \mathrm{C}, \mathrm{a}_{2} / \mathrm{CO}$

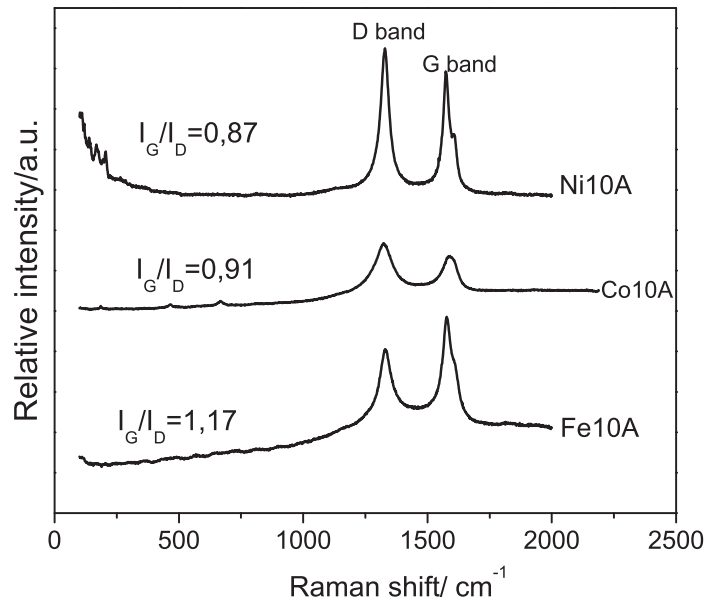

Fig. 3. Raman spectra for composites M/C.

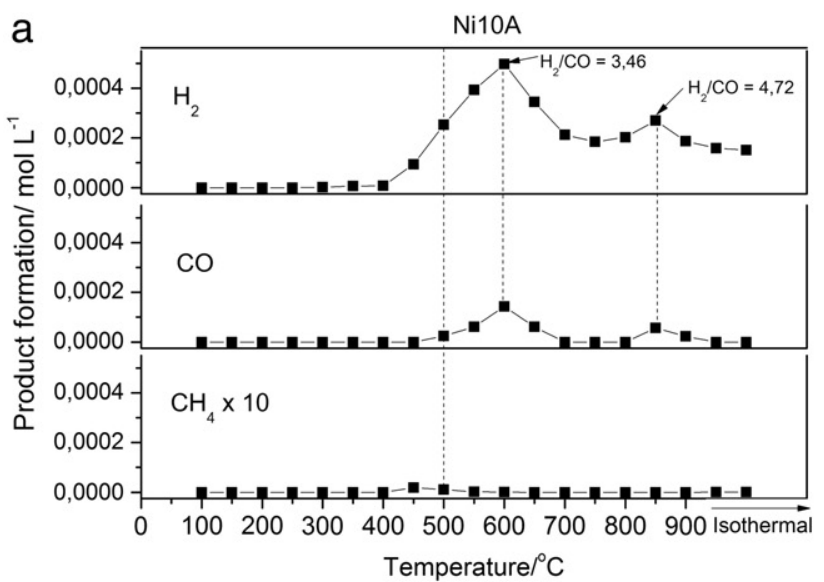

b

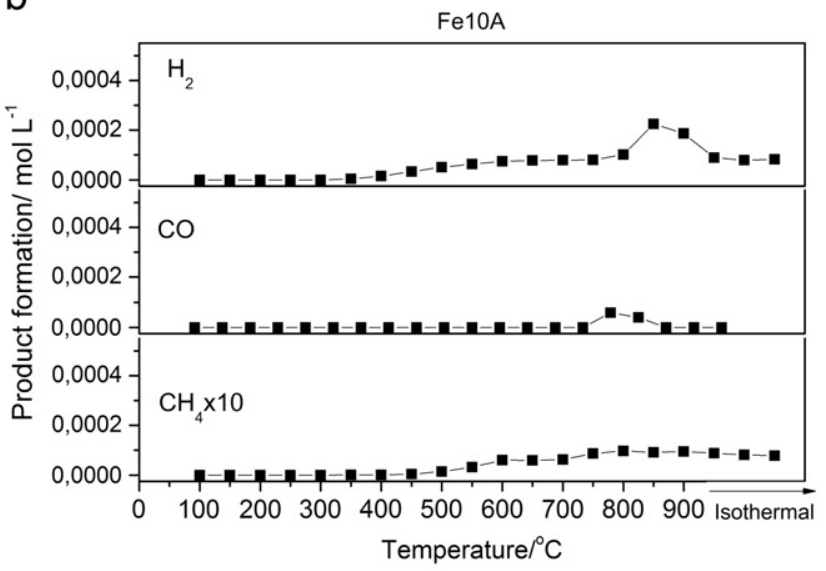

C

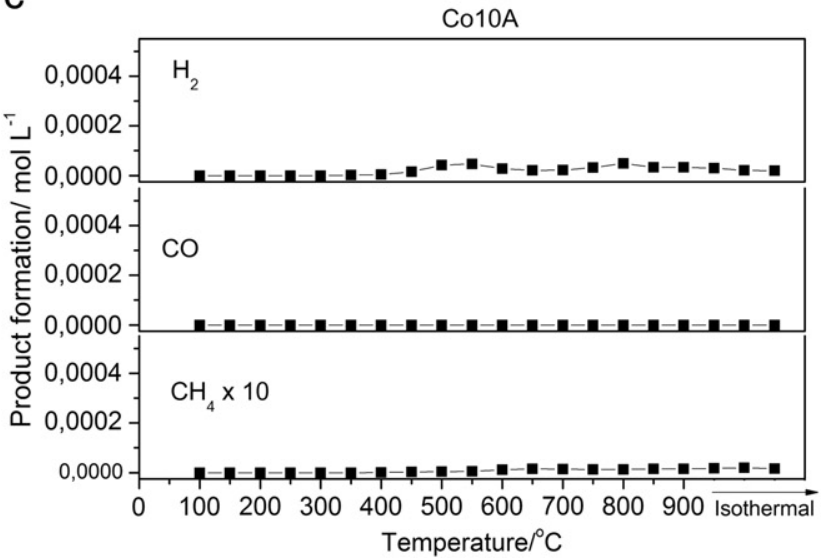

Fig. 4. TPO profiles for composites $\mathrm{M} / \mathrm{C}$ obtained in Step 1:Ni10A (a), Fe10A (b) and Co10A (c).

ratio of ca. 4.7 suggests that the reaction shown in Eq. (5) becomes more important. No $\mathrm{CO}_{2}$ was detected indicating that the water gas shift reaction $\left(\mathrm{H}_{2} \mathrm{O}+\mathrm{CO} \rightarrow \mathrm{H}_{2}+\mathrm{CO}_{2}\right)$ was not present. This is likely related to the complete consumption of $\mathrm{H}_{2} \mathrm{O}$ during reaction.

Fig. $4 \mathrm{~b}$ shows that catalyst $\mathrm{Fe} 10 \mathrm{~A}$ also produced $\mathrm{H}_{2}$ at the initial temperature of $400{ }^{\circ} \mathrm{C}$. On the other hand, $\mathrm{CO}$ is detected only at $800{ }^{\circ} \mathrm{C}$ and $\mathrm{CH}_{4}$ at $500{ }^{\circ} \mathrm{C}$. These results suggest that up to $500{ }^{\circ} \mathrm{C}$, the main process is the oxidation of $\mathrm{Fe}^{\circ}$ by $\mathrm{H}_{2} \mathrm{O}$ similar to $\mathrm{Ni}$ (Eq. (5)). In fact, TPO experiment with a pure $\mathrm{Fe}^{\mathrm{o}}$ sample showed the oxidation by $\mathrm{H}_{2} \mathrm{O}$ in a very similar temperature range (Supplementary Material). Up to $800{ }^{\circ} \mathrm{C}$, significant amounts of methane were formed suggesting carbon deposits oxidation to $\mathrm{CO}$, followed by hydrogenation to $\mathrm{CH}_{4}$. Also, control reaction of the carbon deposited on $\mathrm{Fe} 10 \mathrm{~A}$ with pure $\mathrm{H}_{2}$ showed that 


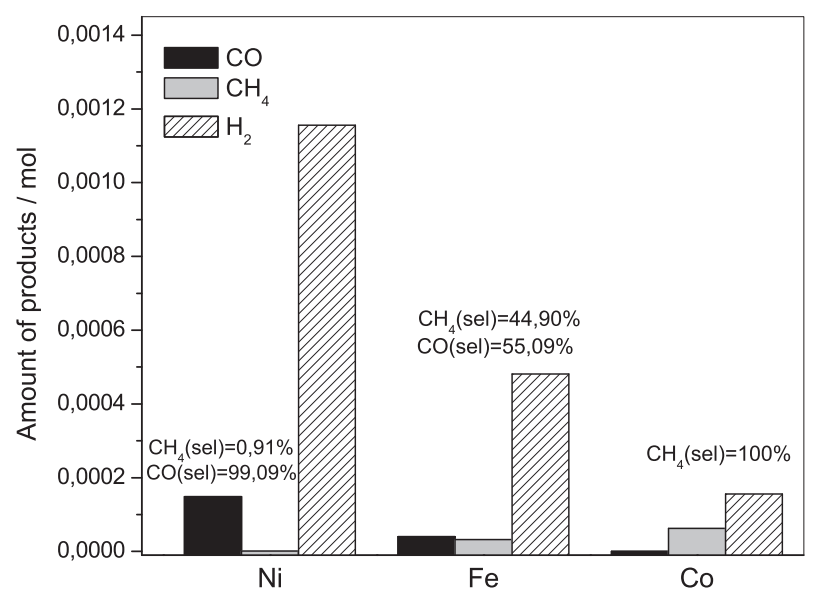

Fig. 5. Total amount of $\mathrm{H} 2, \mathrm{CO}$ and $\mathrm{CH} 4$ production during $\mathrm{H} 2 \mathrm{O}-\mathrm{TPO}$ experiments.

$\mathrm{CH}_{4}$ can be formed by direct hydrogenation in temperature range ca. $600-900{ }^{\circ} \mathrm{C}$ (Supplementary Material):

$\mathrm{C} / \mathrm{Fe}+2 \mathrm{H}_{2} \rightarrow \mathrm{CH}_{4}+\mathrm{Fe}$

It is interesting to observe that the catalyst Fe10A produced much more $\mathrm{CH}_{4}$ compared to Ni10A, i.e. ca. $35 \% \mathrm{CH}_{4}$ (Fig. 5). Other hydrocarbons such as $C_{2}$ and $C_{3}$ were also detected in very small amounts during the reaction with Fe10A suggesting the presence of a Fischer Tropsch (FT) like process (Supplementary Material).

The catalyst Co10A showed small production of $\mathrm{H}_{2}$ but no $\mathrm{CO}$ and high selectivity to methane. As discussed for Fe10A, $\mathrm{H}_{2}$ is formed mainly by the reaction of $\mathrm{H}_{2} \mathrm{O}$ with $\mathrm{Co}$ metal (similar to Eq. (5)) whereas $\mathrm{CH}_{4}$ is formed by the hydrogenation of $\mathrm{CO}$ or direct hydrogenation of the carbon deposits. Traces of $C_{2}$ and $C_{3}$ were also observed due to a FT like hydrogenation catalyzed by cobalt.

The $\mathrm{H}_{2}$ and CO TPO peak intensities for the Ni system is relatively higher compared to the TPO of Fe and Co. This result is related to the more efficient carbon oxidation over the Ni material. In fact, TG after TPO showed almost complete oxidation of the carbon for the Ni system whereas for Fe and Co only ca. $60 \%$ of the carbon was oxidized after TPO.

Fig. 5 shows the total amount of $\mathrm{H}_{2}, \mathrm{CO}$ and $\mathrm{CH}_{4}$ formed during the TPO runs for the different catalysts. The obtained results suggest that the metals $\mathrm{Ni}, \mathrm{Fe}$ and $\mathrm{Co}$ have a strong effect during oxidation of the carbon deposits by $\mathrm{H}_{2} \mathrm{O}$ with an important effect on the $\mathrm{CH}_{4}$ and $\mathrm{CO}$ selectivity.

For Ni10A material, the total $\mathrm{H}_{2} / \mathrm{CO}$ ratio produced during TPO was ca. 5.2. It can also be observed that the deposited carbon is converted mostly to $\mathrm{CO}$ (99\% selectivity) with low selectivity to $\mathrm{CH}_{4}$ (1\%). Fe and $\mathrm{Co}$ are more selective to convert carbon to $\mathrm{CH}_{4}$ compared to $\mathrm{Ni}$, which was expected since these metals are the most active in Fischer Tropsch synthesis. The TPO profiles suggest, specially for Fe10A, that the reaction can be completely selective to $\mathrm{CH}_{4}$ at lower temperatures. The reaction conditions are currently being optimized in order to improve the carbon oxidation and promote the direct carbon conversion into $\mathrm{CH}_{4}$ and other higher hydrocarbons in a single step.

\section{Conclusions}

Catalysts based on $\mathrm{Ni}$, Fe and Co supported on alumina can be used to produce large amounts of carbon which may be stored and transported. These metal/carbon composites (M/C) can then be oxidized with $\mathrm{H}_{2} \mathrm{O}$ to produce $\mathrm{H}_{2}, \mathrm{CO}$ and $\mathrm{CH}_{4}$. The Fe based catalyst (Fe10A) was more efficient in carbon deposition from $\mathrm{CH}_{4}$, promoting mainly the formation of filaments.
TPO experiments showed that the efficiency and selectivity of the carbon oxidation by $\mathrm{H}_{2} \mathrm{O}$ is strongly dependent on the metal. Ni10A system was more efficient to produce $\mathrm{H}_{2}$ and $\mathrm{CO}$ with small amounts of $\mathrm{CH}_{4}$. On the other hand, Fe10A was significantly more selective to convert carbon deposits into $\mathrm{CH}_{4}$ during the oxidation with $\mathrm{H}_{2} \mathrm{O}$. The presence of $C_{2}$ and $C_{3}$ compounds suggests the presence of a Fischer Tropsch like process. TPO results also suggested that the selectivity of carbon conversion to $\mathrm{CO}$ or to $\mathrm{CH}_{4}$ can be controlled by the $\mathrm{H}_{2} \mathrm{O}$ oxidation temperature.

This work is preliminary and further investigation is important to understand the reaction mechanism, identify other hydrocarbons formed and develop catalysts which optimize hydrocarbon production.

\section{Appendix A. Supplementary data}

Supplementary data to this article can be found online at http:// dx.doi.org/10.1016/j.catcom.2012.11.021.

\section{References}

[1] F. Yagi, R. Kanai, S. Wakamatsu, R. Kajiyama, Y. Suehiro, M. Shimura, 104 (2005) 2-6.

[2] B. Bao, M.M. El-Halwagi, N.O. Elbashir, 91 (2010) 703-713.

[3] M.G. Rosmaninho, F.C.C. Moura, L.R. Souza, R.K. Nogueira, G.M. Gomes, J.S. Nascimento, M.C. Pereira, J.D. Fabris, J.D. Ardisson, M.S. Nazzarro, K. Sapag, M.H. Araujo, R.M. Lago, Applied Catalysis B: Environmental 115 (2012) 45-52.

[4] M.F. Bleeker, H.J. Veringa, S.R.A. Kersten, Industrial and Engineering Chemistry Research 49 (2010) 53-64.

[5] H. Wang, G. Wang, X. Wang, J. Bai, Journal of Physical Chemistry C 112 (2008) 5679-5688.

[6] U. Narkiewicz, M. Podsiadly, R. Jedrzejewski, I. Pelech, Applied Catalysis A: General 384 (2010) 27-35.

[7] S. Takenaka, Y. Kobayashi, K. Otsuka, Energy \& Fuels 18 (2004) 1775-1783.

[8] S. Takenaka, M. Ishida, M. Serizawa, E. Tanabe, K. Otsuka, The Journal of Physical Chemistry. B 108 (2004) 11464-11472.

[9] S. Takenaka, H. Ogihara, I. Yamanaka, K. Otsuka, Applied Catalysis A: General 217 (2001) 101-110.

[10] B. Bahrami, A. Khodadadi, Y. Mortazavi, M. Esmaieli, Applied Surface Science 257 (2011) 9710-9716.

[11] F. Pinto, H. Lopes, R.N. Andre, I. Gulyurtlu, I. Cabrita, Fuel 86 (2007) 2052-2063.

[12] J.A. Satrio, B.H. Shanks, T.D. Wheelock, Energy \& Fuels 21 (2007) 322-326.

[13] L. Wang, Y. Hisada, M. Koike, D.L. Li, H. Watanabe, Y. Nakagawa, K. Tomishige, Applied Catalysis B: Environmental 121 (2012) 95-104.

[14] G.Q. Guan, G. Chen, Y. Kasai, E.W.C. Lim, X.G. Hao, M. Kaewpanha, A. Abuliti, C. Fushimi, A. Tsutsumi, Applied Catalysis B: Environmental 115 (2012) 159-168.

[15] L. Di Felice, C. Courson, P.U. Foscolo, A. Kiennemann, International Journal of Hydrogen Energy 36 (2011) 5296-5310.

[16] L.A. Cano, M.V. Cagnoli, N.A. Fellenz, J.F. Bengoa, N.G. Gallegos, A.M. Alvarez, S.G. Marchetti, Applied Catalysis A: General 379 (2010) 105-110.

[17] A.K. Dalai, B.H. Davis, Applied Catalysis A: General 348 (2008) 1-15.

[18] A.A.G. Blanco, M.G. Amaya, M.E.R. Jalil, M. Nazzarro, M.I. Oliva, K. Sapag, Topics in Catalysis 54 (2011) 190-200.

[19] J.M. Thomas, W.J. Thomas, Principles and Practice of Heterogeneous Catalysis, Wiley-VCH, New York, 1996.

[20] A.Y. Khodakov, W. Chu, P. Fongarland, Chemical Reviews 107 (2007) 1692-1744.

[21] A.M. Saib, D.J. Moodley, I.M. Ciobica, M.M. Hauman, B.H. Sigwebela, C.J. Weststrate, J.W. Niemantsverdriet, J. van de Loosdrecht, Catalysis Today 154 (2010) 271-282.

[22] V.U.S. Rao, G.J. Stiegel, A.C. Bose, G.J. Cinquegrane, R.D. Srivastava, Fuel 203 (1992) 26.

[23] S. Logdberg, D. Tristantini, O. Borg, L. Ilver, B. Gevert, S. Jaras, E.A. Blekkan, A. Holmen, Applied Catalysis B: Environmental 89 (2009) 167-182.

[24] I.R. Guimaraes, L.C.A. Oliveira, P.F. Queiroz, T.C. Ramalho, M. Pereira, J.D. Fabris, J.D. Ardisson, Applied Catalysis A: General 347 (2008) 89-93.

[25] I.R. Guimaraes, A. Giroto, L.C.A. Oliveira, M.C. Guerreiro, D.Q. Lima, J.D. Fabris, Applied Catalysis B: Environmental 91 (2009) 581-586.

[26] W. Ferraz, L.C.A. Oliveira, R. Dallago, L. da Conceicao, Catalysis Communications 8 (2007) 131-134.

[27] D. Dasgupta, T. Wiltowski, Fuel 90 (2011) 174-181.

[28] M. Kollar, A. De Stefanis, H.E. Solt, M.R. Mihalyi, J. Valyon, A.A.G. Tomlinson, Journal of Molecular Catalysis A: Chemical 333 (2010) 37-45.

[29] M.A. Vannice, Journal of Catalysis 37 (1975) 449-461.

[30] G.A. Martin, C. Mirodatos, 42 (1995) 179-215.

[31] B.C. Enger, R. Lodeng, A. Holmen, 346 (2008) 1-27.

[32] M.D. Krcha, A.D. Mayernick, M.J. Janik, 293 (2012) 103-115.

[33] K. Otsuka, A. Mito, S. Takenaka, I. Yamanaka, 26 (2001) 191-194.

[34] M.S. Dresselhaus, G. Dresselhaus, R. Saito, A. Jorio, Physics Reports 409 (2005) 47-99. 